\title{
Al-Chizan
}

Jurnal Pemikiran Hukum Islam

ISSN 1907-0985, E ISSN 2442-8256

Vol. 15 , No. 1,2019 , h. $55-80$

DOI: https://doi.org/10.30603/am.v15i1.833

\section{Pencatatan Perkawinan Lintas Kantor Urusan Agama Di Kota Gorontalo}

\section{Alinda Ahmad Ishak dan Muhibbuddin}

Kementerian Agama Kabupaten Gorontalo, IAIN Sultan Amai Gorontalo Email:alind4ishak@gmail.com; muhibiain75@gmail.com

Abstract: This paper aims to find out and analyze marital registration across the Office of Religious Affairs (KUA) in Gorontalo City by observing Circular Letter of the Directorate of Islamic Community Guidance Number: Dj.II.2 / 1 / HM.01 / 942/2009. This research is a descriptive-analytical field research. The approach used is a normative juridical approach with data collection methods in the form of observations, interviews and documentation studies. The results showed that 7 of 9 KUA in the City of Gorontalo, the Headman/Registrar of marriage did not know and read the Circular, while 2 of the $9 \mathrm{KUA}$ in Gorontalo City who have read it are divided into two groups: First, assume that the purpose of the Circular applies only to normal marriages, not to apply to post-isbat marriages; Secondly, despite the contrary opinion, if faced with a real case in the field, Recording of post isbat marriage done by cross-KUA, will still receive and record it even if it is not in accordance with the contents of the circular and follow the court's ruling on the contents of the determination of the isbat. The author is of the opinion that the reality of cross-KUA marriages in Gorontalo does not go according to the rules contained in the Circular, and even seems to be ignored by the Headman/Registrar of marriage.

Keywords: Marriage Isbat, Office of Religious Affairs, Marriage Registration, Circular

\section{Recording Marriage Cross Office of Religious Affairs In Gorontalo City}

Abstrak: Tulisan ini bertujuan untuk mengetahui dan menganalisis pencatatan perkawinan lintas Kantor Urusan Agama (KUA) di Kota Gorontalo dengan memperhatikan Surat Edaran Direktorat Bimbingan Masyarakat Islam Nomor: Dj.II.2/1/HM.01/942/2009. Penelitian ini adalah 
penelitian lapangan yang bersifat deskriptif-analitis. Pendekatan yang digunakan adalah pendekatan yuridis normatif dengan metode pengumpulan data berupa pengamatan, wawancara dan studi dokumentasi. Hasil penelitian menunjukkan bahwa 7 dari 9 KUA Kecamatan di Kota Gorontalo, Penghulu/Pegawai Pencatat Nikah belum mengetahui dan membaca Surat Edaran tersebut. Sementara 2 dari 9 KUA Kecamatan di Kota Gorontalo yang pernah membacanya terpecah menjadi dua kelompok: Pertama, berasumsi bahwa maksud dari Surat Edaran tersebut hanya berlaku untuk perkawinan normal, tidak berlaku untuk perkawinan pasca isbat; Kedua, meskipun berpendapat sebaliknya tetapi kalau dihadapkan kepada kasus nyata di lapangan, pencatatan lintas KUA pasca isbat, tetap akan menerima dan mencatatnya walaupun tidak sesuai dengan isi dari surat edaran dan mengikuti amar putusan Pengadilan pada isi penetapan isbat-nya. Penulis berpendapat realitas pencatatan perkawinan lintas KUA di Kota Gorontalo tidak berjalan sesuai dengan aturan yang terdapat dalam Surat Edaran tersebut, bahkan terkesan diabaikan oleh para Penghulu/Pegawai Pencatat Nikah.

Kata Kunci: Isbat Nikah, Kantor Urusan Agama, Pencatatan Perkawinan, Surat Edaran

\section{A. Pendahuluan}

Pencatatan perkawinan di Indonesia memiliki aturan hukum yang bersumber dari peraturan perundang-undangan, misalnya Undang-Undang Nomor 1 Tahun 1974 tentang Perkawinan (selanjutnya UUP) dan Instruksi Presiden Nomor 1 Tahun 1991 tentang Kompilasi Hukum Islam (selanjutnya KHI). Dalam ketentuan pasal 2 ayat (2) UUP disebutkan "Tiap-tiap perkawinan dicatat menurut peraturan perundang-undangan yang berlaku." Juga dalam KHI pasal 7 ayat (diyatakan "Perkawinan hanya dapat dibuktikan dengan akta nikah yang dibuat oleh Pegawai Pencatat Nikah."

Pencatatan dilakukan oleh Pegawai Pencatat Nikah (selanjutnya disebut PPN) sebagaimana dimaksud oleh Undang-Undang Nomor 32 Tahun 1954 tentang Pencatatan Perkawinan, Talak dan Rujuk. Sedangkan tata cara pencatatannya berpedoman kepada ketentuan Peraturan Pemerintah Nomor 9 Tahun 1975, pasal 10 ayat (3). Peraturan Pemerintah tersebut menentukan Perkawinan dilaksanakan di hadapan Pegawai Pencatat yang dihadiri oleh 
Alinda Ahmad Ishak, Muhibbuddin

dua orang saksi. ${ }^{1}$ Tujuan pencatatan yang dilakukan di hadapan dan di bawah pengawasan Pegawai Pencatat Nikah (PPN) menurut KHI adalah untuk terjaminnya ketertiban perkawinan. Perkawinan yang dilakukan di luar pengawasan PPN tidak mempunyai kekuatan hukum, karena perkawinan hanya dapat dibuktikan dengan Akta Nikah yang dibuat oleh PPN. $^{2}$

Tampak bahwa sahnya suatu perkawinan selain didasarkan atas agama dan kepercayaan juga harus didaftarkan kepada Pegawai Pencatat Nikah yang berwenang. Pencatatan perkawinan dimaksudkan untuk menjadikan peristiwa perkawinan itu menjadi jelas dan diakui oleh negara. Hal itu penting untuk menentukan kedudukan hukum seseorang, dimana kedudukan hukum tersebut, membawa serta hak dan kewenangan tertentu untuk bertindak dalam hukum. Sahnya perkawinan diatur dalam pasal 2 ayat (1) UUP yang menyebutkan "Perkawinan adalah sah apabila dilakukan menurut hukum masing-masing agamanya dan kepercayaannya itu."

Sebuah perkawinan adalah sah apabila dilakukan menurut hukum masing-masing agamanya dan kepercayaannya itu. Ini berarti jika suatu perkawinan telah memenuhi syarat dan rukun perkawinan atau ijab kabul telah dilaksanakan (bagi umat Islam) atau pendeta/pastur telah melaksanakan pemberkatan atau ritual lainnya, maka perkawinan tersebut adalah sah terutama di mata agama dan kepercayaan masyarakat. Selain sahnya perkawinan di mata agama dan kepercayaan masyarakat perlu disahkan pula oleh negara melalui pencatatan perkawinan, dalam hal ini ketentuannya terdapat pada pasal 2 ayat 2 UUP yang teknis pencatatan perkawinan diatur pada pasal 2 PP No. 9 Tahun 1975 tentang Pencatatan Perkawinan.

Bagi mereka yang melakukan perkawinan menurut agama Islam, pencatatan dilakukan di KUA. Sedangkan untuk mencatatkan perkawinan dari mereka yang beragama dan kepercayaan selain Islam, cukup menggunakan dasar hukum Pasal 2 Ayat 2 PP No. 9 Tahun 1975 bahwa "Perkawinan yang telah melalui pencat atan mengandung kemaslahatan bagi umum, artinya perkawinan tersebut melindungi hak asasi kaum wanita,

${ }^{1}$ Anshary MK, Hukum Perkawinan di Indonesia (Cet. II; Yogyakarta: Pustaka Pelajar, 2015), 19.

${ }^{2}$ Khairuddin Nasution, Hukum Perdata (Keluarga) Islam Indonesia dan Perbandingan Hukum Perkawinan di Dunia Muslim (Yogyakarta: Academia \& Tazzafa, 2009), 338. 
sebab menurut hukum positif Indonesia, perkawinan yang tidak dicatatkan atau perkawinan di bawah tangan tidak diakui sama sekali oleh Negara." Pentingnya pencatatan pernikahan ini walaupun tidak secara tekstual dijelaskan dalam Alquran, tetapi dapat diketahui bahwa pernikahan adalah sebuah konsep hubungan manusia dengan manusia, dalam hal ini mumalah secara umum (QS al-Baqarah/2: 282).

Pencatatan ini sudah menjadi tugas dari KUA di Kecamatan. Khususnya Kota Gorontalo yang merupakan Ibukota Provinsi Gorontalo memiliki 9 Kecamatan dan dalam setiap kecamatan terdapat satu KUA, yaitu: (1) KUA Kecamatan Kota Selatan; (2) KUA Kecamatan Kota Utara; (3) KUA Kecamatan Kota Barat; (4) KUA Kecamatan Kota Timur; (5) KUA Kecamatan Kota Tengah; (6) KUA Kecamatan Dungingi; (7) KUA Kecamatan Dumbo Raya (8) KUA Kecamatan Hulonthalangi; (9) KUA Kecamatan Sipatana.

Kota Gorontalo yang berpenduduk mayoritas muslim sangat signifikan dalam melayani kebutuhan masyarakat, khususnya di bidang pengawasan dan pencatatan perkawinan. Perkawinan bisa saja dilakukan secara normal dan ada juga yang melalui proses perkawinan sirri, untuk selanjutnya melakukan permohonan isbat nikah untuk mengesahkan perkawinannya. Data dari Pengadilan Agama Gorontalo yang yurisdiksinya mewilayahi seluruh wilayah Kota Gorontalo, sepanjang tahun 2017 menerima permohonan isbat nikah sebanyak kurang lebih 102 perkara. ${ }^{4}$ Dari hasil pengamatan sementara yang penulis lakukan di KUA Kecamatan Kota Selatan, ada beberapa peristiwa unik yang ditemukan, diantaranya adanya peristiwa perkawinan sirri yang dilangsungkan di luar Provinsi Gorontalo, yang telah disahkan oleh Pengadilan Agama Gorontalo. ${ }^{5}$ Kedua peristiwa perkawinan tersebut kemudian dicatatkan di KUA Kecamatan Kota Selatan.

Tidak terkecuali pada perkawinan pasca isbat, dalam perkawinan normalpun, masih terjadi penyimpangan yang sama, dimana ada perkawinan dilangsungkan di wilayah Kecamatan A misalnya, tetapi penghulunya

${ }^{3}$ http://intanghina.wordpress.com/2008/05/27/analisis-yuridis-status-hukum-istriyang-menikah-di-bawah-tangan-berdasarkan-ketentuan-yang-berlaku-tentang-perkawinan, diakses tanggal 30 Januari 2018.

${ }^{4}$ Lihat LIPA 1.pdf, dalam www.pa-gorontalo.go.id, diakses pada tanggal 30 Januari 2018.

${ }^{5}$ Lihat Salinan Penetapan Nomor 0276/Pdt.P/2015/PA.Gtlo; dan Salinan Penetapan Nomor 0251/Pdt.P/2014/PA.Gtlo; 
berasal dari KUA Kecamatan B. Kasus seperti ini umumnya terjadi pada perkawinan yang dilaksanakan di gedung resepsi perkawinan yang disewakan untuk umum, yang kebetulan lokasi gedungnya berada di luar kecamatan domisili kedua calon mempelai. Sebagai contoh, perkawinan antara Lk A, yang beralamat di Kelurahan Huangobotu, Kecamatan Dungingi dengan Pr. B beralamat di Jl. Taman Hiburan, Kelurahan Wonggaditi Barat, Kecamatan Kota Utara, dimana proses akad nikahnya dilangsungkan di Gedung Graha Azizah yang terletak di Jl. Manggis, Kelurahan Molosipat W, Kecamatan Kota Barat, Kota Gorontalo di bawah pengawasan Penghulu dari KUA Kecamatan Kota Utara dan perkawinannya dicatatkan di KUA Kecamatan Kota Utara dengan nomor Kutipan Akta Nikah 009/013/V/2016. ${ }^{6}$

Pertanyaan mendasar muncul apakah KUA Kecamatan Kota Selatan pada kasus pertama dan KUA Kecamaan Kota Utara pada kasus kedua berwenang mencatat peristiwa perkawinan tersebut? sementara menurut aturan pencatatan perkawinan, -baik perkawinan normal (resmi), ${ }^{7}$ maupun perkawinan sirri pasca penetapan isbat oleh Pengadilan, ${ }^{8}$-seluruhnya mengandung norma hukum yang sama, yaitu pencatatan perkawinan menganut asas tempat terjadinya peristiwa perkawinan, bukan domisili. Artinya apabila terjadi perbedaan antara tempat berlangsunya peristiwa perkawinan dengan domisili pengantin, maka yang berwenang mencatat perkawinan adalah PPN yang mewilayahi tempat dilangsungkannya

${ }^{6}$ Fitri Mifta Huda Manoppo, Mempelai Perempuan, Wawancara di Kota Gorontalo tanggal 18 April 2018.

${ }^{7}$ Seperti Undang-Undang Nomor 22 Tahun 1946 tentang Pencatatan Perkawinan, Talak dan Rujuk jis. Undang-Undang Nomor 32 Tahun 1954 tentang Pemberlakuan UndangUndang Nomor 22 Tahun 1946 di seluruh wilayah RI, pasal 2 ayat (2) Undang-Undang Nomor 1 Tahun 1974, Pasal 2 ayat (1) Peraturan Pemerintah Nomor 9 Tahun 1975 tentang Pelaksanaan Undang-Undang Nomor 1 Tahun 1974, pasal 7 ayat (1) Kompilasi Hukum Islam, dan Peraturan Menteri Agama Republik Indonesia Nomor 11 Tahun 2017 tentang Pencatan Perkawinan

${ }^{8}$ Seperti diatur dalam pasal 3 ayat (5) Undang-undang Nomor 32 Tahun 1954 tentang Pencatatan Perkawinan, Talak dan Rujuk. Teks lengkapnya sebagai berikut : "Djika terdjadi salah satu hal jang tersebut pada ajat pertama, kedua dan ketiga dan ternjata karena keputusan hakim, bahwa ada orang kawin tidak dengan mentjukupi sjarat pengawasan atau ada talak atau rudjuk tidak diberitahukan kepada jang berwajib, maka biskalgripir hakim kepolisian jang bersangkutan mengirim salinan keputusannja kepada pegawai pentjatat nikah jang bersangkutan dan pegawai itu memasukkan nikah, talak dan rujuk itu di dalam buku pendaftaran masing-masing dengan menjebut surat keputusan hakim jang menjatakan hal itu". 
peristiwa perkawinan, bukan PPN dimana domisili para pengantin. Hal ini ditegaskan dalam Surat Edaran Dirjen Bimas Islam Nomor: D II.2/1/HM.01/942/2009 tentang Asas Pencatatan Perkawinan. Dalam butir 3 Surat Edaran tersebut dijelaskan: bahwa berdasarkan ketentuan tersebut di atas, PPN tidak boleh mencatat pernikahan di luar wilayah hukumnya, karena asas pencatatan adalah menganut asas tempat terjadinya peristiwa, bukan domisili.

Surat Edaran tersebut, sepintas memang terlihat hanya mengatur tentang perkawinan normal (resmi),-terutama pada ayat (1) dan (2)- akan tetapi asas pencatatan nikah yang ditegaskan dalam Surat Edaran tersebut adalah asas umum pencatatan perkawinan, dimana asas tersebut tidak hanya berlaku untuk perkawinan normal saja tetapi menjangkau semua jenis perkawinan yang dianggap sah dan legal oleh aturan perundangan, termasuk di dalamnya adalah perkawinan sirri pasca penetapan oleh Pengadilan. Hal ini sebagaimana ditegaskan oleh Penetapan Pengadilan Agama Kediri Nomor 0054/Pdt.P/2016/PA.Kdr. tanggal 23 Mei 2016. ${ }^{9}$ Dalam pertimbangan hukumnya Majelis Hakim yang menangani permohonan isbat nikah tersebut, mengutip Surat Edaran dimaksud untuk menentukan KUA mana yang berwenang melakukan pencatatan nikah pasca penetapan::

Menimbang, bahwa berdasarkan Surat Edaran Dirjen Bimas Islam Nomor D II.2/1/HM.01/942/2009 tanggal 2 Juni 2009 tentang asas Pencatatan Perkawinan, maka ditegaskan bahwa asas pencatatan menganut asas tempat terjadinya perkawinan, bukan domisili. Oleh karena itu, PPN yang berhak mencatat adalah PPN yang mewilayahi tempat dilangsungkannya perkawinan.

Menimbang, bahwa berdasarkan ketentuan dan kaidah tersebut, Majelis memerintahkan kepada Pemohon I dan Pemohon II untuk mendaftarkan perkawinan tersebut kepada Pegawai Pencatat Nikah KUA Kecamatan Camplong ${ }^{10}$, Kabupaten Sampang agar dicatat perkawinan tersebut. ${ }^{11}$

${ }^{9}$ https://putusan.mahkamahagung.go.id, diakses pada tanggal tanggal 18 April 2018.

${ }^{10}$ Kecamatan Camplong, adalah tempat dilaksanakannya perkawinan sirri kedua mempelai, tepatnya di Desa Rembang, Kecamatan Camplong Kabupaten Sampang, sedangkan domisili keduanya pada saat mengajukan isbāt nikah berada di Kota Kediri, tepatnya di Kecamatan Pesantren.

${ }^{11}$ Penetapan Pengadilan Agama Kediri Nomor: 0054/Pdt.P/2016/PA.Kdr. tanggal 23 Mei 2016. 
Alinda Ahmad Ishak, Muhibbuddin

Penetapan tersebut mengesahkan perkawinan yang terjadi antara Pemohon I dengan Pemohon II yang dilangsungkan secara sirri pada tanggal 9 Mei 1998 di Desa Rembang, Kecamatan Camplong, Kabupaten Sampang. Kemudian kedua mempelai pindah domisili di Kota Kediri, tepatnya di Kecamatan Pesantren, Kota Kediri, sehinga permohonan isbat-nya diajukan ke Pengadilan Agama Kota Kediri.

Penetapan tersebut jelas menentukan bahwa yang berhak mencatat adalah KUA dimana perkawinan sirri dahulu dilaksanakan yaitu KUA Kecamatan Camplong, Kabupaten Sampang, bukan KUA tempat domisili sekarang dimana kedua mempelai berdomisili yaitu di Kota Kediri, tepatnya KUA Kecamatan Pesantren Kota Kediri. ${ }^{12}$ Di sini nampak bahwa dalam mengimplementasikan Surat Edaran tersebut terdapat adanya perbedaan pemahaman.

\section{B. Asas Perkawinan dan Pencatatan Perkawinan}

Penetapan Pengadilan Agama Kediri Nomor 0054/Pdt.P/2016/ PA.Kdr dan Surat Edaran Dirjen Bimas Islam Nomor: D II.2/1/HM. 01/942/2009 tentang Asas Pencatatan Perkawinan sepintas terdengar seperti tidak ada perbedaan yang signifikan, ibarat sebuah koin mata uang, maka asas perkawinan berada pada sisi depan koin sedangkan asas pencatatan perkawinan berada pada bagian belankangnya, akibatnya banyak orang yang salah menempatkan antara kedua asas tersebut, bahkan yang lebih tragis lagi ada diantara pemangku kebijakan dalam hal ini Penghulu/PPN, belum memahami tentang kedua asas tersebut. ${ }^{13}$

Sehubungan dengan hal itu, maka kedua asas tersebut perlu dijelaskan, hal ini penting untuk diketahui mengingat kebutuhan masyarakat kian berkembang dan membutuhkan pelayanan yang mudah- "(bukan dipermudah)"- dan cepat serta kepastian hukum sesuai dengan asas pelayanan publik yang baik dan benar. Disebutkan dalam Peraturan Pemerintah (PP) No. 9 Tahun 1975 tentang Pelaksanaan UU No. 1 Tahun 1974 tentang Perkawinan pada pasal 3 ayat (1) menyebutkan: Mei 2016.

${ }^{12}$ Penetapan Pengadilan Agama Kediri Nomor: 0054/Pdt.P/2016/PA.Kdr. tanggal 23

${ }^{13}$ Hasil wawancara dengan beberapa Penghulu di KUA Kecamatan Wilayah Kota Gorontalo pada tanggal 4 Juli 2018. 


\section{Pencatatan Perkawinan Lintas Kantor Urusan Agama \\ Di Kota Gorontalo}

Setiap orang yang akan melangsungkan perkawinan memberitahukan kehendaknya itu kepada Pegawai Pencatat di tempat perkawinan akan dilangsungkan. ${ }^{14}$

Selanjutnya untuk memperjelas diatur dalam Registerulasi turunannya, yaitu dalam Peraturan Menteri Agama (PMA) No. 11 Tahun 2007 tentang Pencatatan Nikah dalam pasal 17 disebutkan:

1) Akad nikah dilaksanakan dihadapan PPN atau penghulu atau pembantu PPN dari wilayah tempat tinggal calon istri.

2) Apabila akad nikah akan dilaksanakan diluar ketentuan sebagaimana dimaksud pada ayat (1), maka calon isteri atau walinya harus memberitahukan kepada PPN diwilayah tempat tinggal calon istri untuk mendapatkan surat rekomendasi nikah. ${ }^{15}$

Maksud dari ayat (2) pasal 17 ini adalah jika akad nikah akan dilaksanakan selain di tempat tinggal calon isteri, semisal di kediaman calon suami, dikediaman wali atau tempat lainnya maka harus memberitahukan kepada PPN di wilayah tempat tinggal calon isteri untuk mendapatkan surat rekomendasi, kemudian kehendak nikah tersebut didaftarkan pada PPN dimana peristiwa akad nikah akan dilangsungkan.

Penjelasan lebih rinci tentang asas pencatatan perkawinan ini dijelaskan pula dalam Surat Edaran Dirjen Bimas Islam No. DJ.II.2/1/HM.01/942/2009 tanggal 29 Juni 2009 pada butir 3 menyatakan bahwa berdasarkan ketentuan tersebut diatas, PPN tidak boleh mencatat

${ }^{14}$ Mahkamah Agung RI., Himpunan Peraturan Perundang-Undangan di Lingkungan Peradilan Agama, (Jakarta: Direktorat Jenderal Badan Peradilan Agama, 2016), 826.

${ }^{15}$ PMA ini meskipun telah direvisi oleh PMA Nomor 19 Tahun 2018, tetapi norma hukum yang terkandung dari dari keduaayat dalam pasal tersebut, substansinya masih relevan dan berlaku karena dimuat kembali dalam pasal 16 PMA No. 19 Tahun 2018 dengan penambahan (di sisipi) ayat (2), sebagai berikut:

1) Akad dilaksanakan di hadapan Kepala KUA Kecamatan atau Penghulu yang mewilayahi tempat akad dilaksanakan.

2) Dalam hal pelaksanaan akad dilaksanakan di daerah terdalam, terluar, dan di daerah perbatasan, Kepala KUA Kecamatan dapat menugaskan P4;

3) Akad yang dilaksanakan di luar tempat tinggal calon suami dan calon istri harus mendapatkan surat rekomendasi perkawinan dari Kepala KUA Kecamatan atau penghulu wilayah tempat tinggal masing-masing; 
Alinda Ahmad Ishak, Muhibbuddin

pernikahan di luar wilayah hukumnya, karena asas pencatatan adalah menganut asas tempat terjadinya peristiwa bukan domisili.

Salah satu contoh kasus, ada seorang calon suami yang berdomisili sesuai KTP misalnya di Kecamatan Kota Barat, Kota Gorontalo akan menikahi calon isterinya yang beralamat/berdomisili di Kecamatan Kota Utara, Kota Gorontalo, berencana akan melangsungkan acara akad nikahnya di salah satu gedung resepsi perkawinan di wilayah Kecamatan Kota Selatan, Kota Gororntalo, maka cukup membawa persyaratan nikah dari daerah domisilinya masing-masing dengan rekomendasi Penghulu/PPN setempat selanjutnya mendaftarkan permohonan nikahnya pada KUA Kecamatan Kota Selatan, Kota Gorontalo yang mewilayahi tempat pelaksanaan akad nikah dan akan dihadiri dan dicatat oleh Penghulu/PPN Kecamatan Kota Selatan, Kota Gorontalo, bukan oleh Penghulu/PPN dari wilayah domisili calon pengantin perempuan.

Aturan tersebut sebagimana yang telah dijelaskan berlaku juga untuk kasus pencatatan perkawinan pasca iśbàt nikah. Dalam kasus iśbàt nikah, jika Lk. A dan Pr. B melangsungkan pernikahan secara sirri di Kelurahan Bugis, Kecamatan Dumbo raya, Kota Gorontalo, sesuai dengan domisili keduanya pada saat itu. Beberapa tahun kemudian, keduanya menetap di Kelurahan Moodu, Kecamatan Kota Timur, Kota Gorontalo, dan mengesahkan perkawinan mereka melalui Pengadilan Agama Gorontalo. Maka dalam kasus ini, yang berwenang mencatat perkawinan tersebutbedasarkan asas pencatatan perkawinan- semestinya adalah Penghulu/PPN pada KUA Kecamatan Dumbo Raya (tempat peristiwa nikah), bukan PPN pada Kecamatan Kota Timur (tempat domisili sekarang).

Kesimpulannya antara perkawinan dan pencatat perkawinan tedapat dua asas yang berbeda. Asas perkawinan merujuk kepada domisili kedua calon mempelai. Artinya dimana calon pengantin perempuan berdomisili, maka disitulah dilaksanakan perkawinannya di hadapan Penghulu/PPN setempat. Sedangkan asas pencatatan perkawinan adalah peristiwa nikah. Artinya dimana peristiwa nikah itu dilaksanakan, maka di wilayah itulah perkawinannya dicatat oleh Penghulu/PPN setempat. Itulah sebabnya mengapa calon pengantin yang hendak melaksanakan perkawinannya di luar alamat domisilinya harus mendapatkan rekomendasi dari Penghulu/PPN tempat domisili kepada Penghulu/PPN tempat berlansungnya penkawinan, agar kedua asas ini secara tidak tumpang tindih dan tetap terjaga maka secara administrasif buku Kutipan Akta Nikah sebagai satu-satunya bukti 
otentik (probationis causa) yang membuktikan bahwa telah tejadinya peristiwa nikah, dipandang legal.

Sebaliknya jika hal keadaan ini hanya dianggap sebelah mata dan dilanggar, maka buku kutipan akta nikah tersebut terdapat cacat hukum dan dianggap illegal. Akibatnya kedua mempelai berpotensi menghadapi permasalahan hukum di kemudian hari, dan itu sangat merugikan kepentingan hukum keduanya.

\section{Perspektif Penghulu di Kota Gorontalo terhadap Surat Edaran Dirjen Bimas Islam Nomor: DII.2/1/HM.01/942/2009}

Setelah dilakukan wawancara dengan para Penghulu/Pegawai Pencatat Nikah (PPN) yang terdapat di KUA se-wilayah Kota Gorontalo, maka ditemukan data faktual mengenai perspektif atau pendapat mereka terhadap asas pencatatan perkawinan, sebagaimana maksud dari Surat Edaran Dirjen Bimas Islam Nomor: DII.2/1/HM.01/942/2009, yaitu:

1. KUA Kecamatan Kota Selatan

Selama saya ditugaskan sebagai penghulu di beberapa KUA dari tahun 2009 sampai dengan sekarang saya pernah mendengar tentang surat edaran yang saudara maksudkan, tetapi saya lupa apa isinya. Akan tetapi setelah saya membacanya sekarang, menurut saya, maksud dari surat tersebut hanya berlaku untuk perkawinan normal, tidak dapat diterapkan pada kasus isbat nikah. Dalam kasus isbat nikah saya mencatat berdasarkan penetapan pengadilan, selagi tidak dipermasalahkan, mengingat pihak tersebut sudah tinggal dan berdomisili di wilayah kecamatan Kota Selatan. ${ }^{16}$

2. Penghulu KUA Kecamatan Kota Utara

Sampai sekarang ini saya belum pernah mendengar perihal surat edaran yang saudara tanyakan. Adapun mengenai pencatatan perkawinan selama ini sudah berjalan sesuai prosedurnya, dan kalau perkawinan pasca issbāt nikah, saya mencatat sesuai dengan domisili kedua mempelai. ${ }^{17}$

\footnotetext{
${ }^{16}$ H. Syamsul Bahri, Kepala KUA Kecamatan Kota Selatan, Wawancara, di KUA Kecamatan Kota Selatan, Kota Gorontalo, tanggal 4 Juni 2018.

${ }^{17}$ H. M. Fahrie Hioda, Kepala KUA Kecamatan Kota Utara, Wawancara, di KUA Kecamatan Kota Utara, Kota Gorontalo, 6 Juli 2018.
} 
3. Penghulu KUA Kecamatan Kota Timur

Saya tidak pernah mendengar atau mengetahui surat edaran tersebut, selama saya menjalankan tugas sebagai Penghulu atau sebagai kepala KUA. Mengenai pencatatan perkawinan pasca issba selama ini saya berpedoman pada hasil penetapan Pengadilan dan kalau ada yang datang mencatatkan perkawinannya akan saya catat selama yang bersangkutan tinggal di wilayah Kecamatan Kota Timur. ${ }^{18}$

4. Penghulu KUA Kecamatan Kota Barat

Selama ini saya belum pernah mendengar atau membaca surat edaran tersebut. Apa isi dari surat edaran tersebut saya tidak mengetahuinya. Tetapi kalau yang saudara pertanyakan mengenai pencatatan perkawianan pasca išbat, selama ini kami mencatatnya sesuai dengan isi penetapan. Kami tidak pernah menolak selama perkawinannya telah disahkan oleh pengadilan. ${ }^{19}$

5. Penghulu KUA Kecamatan Kota Tengah

Mengenai surat edaran yang saudara maksud, sepintas saya pernah mendengar tetapi tidak tahu isinya apa. Tetapi kalau yang saudara maksudkan adalah pencatatan perkawinan lintas KUA pasca penetapan isbat nikah, di KUA ini sejak tahun 2015 sampai sekarang saya belum pernah menerima permohonan pencatatan seperti itu, yang ada hanyalah saya yang merekomendasikan pencatatan perkawinan ke wilayah KUA yang lain. ${ }^{20}$

6. Penghulu KUA Kecamatan Dungingi

Selama saya menjabat kepala KUA kurang lebih 8 (delapan tahun), surat edaran tersebut sudah saya baca dan pelajari serta diterapkan secara maksimal, kecuali terhadap pencatatan nikah pasca penetapan pengadilan belum terlaksana secara optimal. Kendalanya

\footnotetext{
${ }^{18}$ H. Arifin Adam, Kepala KUA Kecamatan Kota Timur, Wawancara, di KUA Kecamatan Kota Timur, Kota Gorontalo , 13 Juli 2018.

${ }^{19}$ Yunus Assaqaf, Penghulu KUA Kecamatan Kota Barat, Wawancara, di KUA Kecamatan Kota Barat, Kota Gorontalo, 13 Juli 2018.

${ }^{20}$ Muhammad Idrus Umar, Kepala KUA Kecamatan Kota Tengah, Wawancara, Gorontalo, 27 Juli 2018
} 


\section{Pencatatan Perkawinan Lintas Kantor Urusan Agama}

Di Kota Gorontalo

adalah amar penetapan pengadilan memerintahkan untuk dicatat di KUA Kecamatan Dungingi. Saya selaku kepala KUA sekaligus penghulu hanya menjalankan isi penetapan pengadilan. ${ }^{21}$

Sejak saya diangkat sebagai penghulu dari tahun 2009 sampai dengan sekarang, saya belum pernah mendengar atau mengetahui perihal adanya edaran dimaksud. Tetapi kalau maksud dari surat edaran tersebut mengenai asas pencatatan perkawinan, sebagaimana keterangan saudara nampaknya sudah berjalan sebagaimana mestinya. Kecuali untuk kasus isbat nikah, itu tergantung dari isi penetapan, kalau dalam penetapan tersebut diperintahkan dicatat di KUA ini, maka akan kami catat sesuai dengan penetapan tersebut, meskipun peristiwa perkawinannya dahulu dilaksanakan di luar wilayah Kecamatan Dungingi. ${ }^{22}$

7. Penghulu KUA Kecamatan Hulonthalangi

Saya pernah mendengar perihal surat edaran tersebut, tetapi belum pernah membacanya. Kalau saya perhatikan setelah saya membacanya dari tangan saudara, maksud atau kandungan dari surat edaran tersebut, menurut saya dapat diterapkan untuk setiap jenis perkawinan, baik perkawinan normal atau perkawinan pasca isbat, tetapi kalu saya pribadi dihadapkan dengan kasus seperti yang saudara teliti, maka tetap akan saya catat semata-mata karena pertimbangan kemanusiaan. ${ }^{23}$

\section{Penghulu KUA Kecamatan Sipatana}

Saya belum pernah melihat dan membaca surat edaran tersebut, akan tetapi setelah saya membacanya sekarang dari tangan saudara, menurut saya asas pencatatan yang dimaksud surat edaran tersebut berlaku umum untuk semua jenis perkawinan, saya perpendapat pencatatan lintas KUA tidak dibenarkan kecuali mendapatkan rekomendasi dari KUA setempat, untuk perkawinan yang akan dilangsungkan di luar domisili calon pengantin perempuan,

${ }^{21}$ Ismail, M.H., Kepala KUA Kecamatan Dungingi, Wawancara, Gorontalo, 12 Juli 2018 .

${ }^{22}$ Zulkifli Tolinggi, Penghulu KUA Kecamatan Dungingi, Wawancara, Gorontalo .12 Juli 2018.

${ }^{23}$ Mohamad Fikri Hioda, Kepala KUA Kecamatan Hulonthalangi, Wawancara, Gorontalo, 19 Juli 2018. 
sementara untuk kasus perkawinan itsbat nikah, tidak akan saya catat sepanjang pernikahannya dahulu dilaksanakan di luar KUA Kecamatan Sipatana dan kebetulan di wilayah kecamatan Sipatana belum saya temui kasus seperti yang saudara angkat dalam penelitian saudara. ${ }^{24}$

\section{Penghulu KUA Kecamatan Dumbo Raya}

Selama bertugas sebagai Penghulu, saya belum pernah mendengar adanya surat edaran yang saudara tanyakan. Adapun mengenai pencatatan perkawinan selama ini sudah berjalan sesuai prosedurnya, dan kalau perkawinan pasca isbat, saya mencatat sesuai dengan domisili kedua mempelai. ${ }^{25}$

Mencermati pendapat para Penghulu tersebut di atas, dari sembilan KUA Kecamatan terdapat 7 (tujuh) KUA Kecamatan yang belum mengetahui adanya surat edaran tersebut, sementara 2 (dua) KUA Kecamatan yang pernah membacanya terpecah menjadi dua kelompok, yang pertama, berasumsi bahwa maksud dari surat edaran tersebut hanya berlaku untuk perkawinan normal, tidak berlaku untuk perkawinan pasca is bät. Sementara kelompok kedua meskipun berpendapat sebaliknya tetapi kalau dihadapkan kepada kasus nyata (di lapangan) pencatatan lintas KUA pasca $i \dot{s} b \bar{a}$, tetap akan menerima dan mencatatnya walaupun tidak sesuai dengan isi dari surat edaran, tergantung pada isi penetapan iśba t-nya. Andaikata dalam penetapan pun tidak menentukan di KUA mana harus dicatat sebagian KUA tetap akan menerima dan mencatatnya semata-mata karena faktor kemanusiaan (pendapat Kepala KUA Hulonthalangi).

Berdasarkan hasil wawancara tersebut, penulis menemukan fakta bahwa Surat Edaran tersebut, belum diterapkan secara optimal, relatif masih terjadi penyimpangan dalam praktek di lapangan dan faktor yang paling dominan yang menyebakan penyimpangan tersebut adalah ketidaktahuan para Penghulu perihal isi surat edaran dimaksud karena kurang tersosialisasi. Padahal surat tersebut sudah berusia kurang lebih 10 tahun lamanya sejak diterbitkan, tepatnya pada tanggal 29 Juni 2009.

\footnotetext{
${ }^{24}$ Jamil, S.Ag, Kepala KUA Kecamatan Sipatana, Wawancara, Gorontalo, 5 Juni 2018.

${ }^{25}$ Ibrahim Daeng Salasa, S.Ag, Kepala KUA Kecamatan Dumbo Raya, Wawancara, Gorontalo, 5 Juni 2018.
} 


\section{Realitas Pencatatan Perkawinan Lintas KUA di Kota Gorontalo}

\section{Pasca Penetapan Isbat Nikah}

Hasil wawancara dan observasi lapangan di 9 (sembilan) KUA Kecamatan di Kota Gorontalo, dengan memeriksa register pencatatan peristiwa nikah mulai dari tahun 2015 sampai dengan Februari 2019, ditemukan data sebagai berikut:

Tabel 1

Peristiwa Nikah Pasca Isbat Nikah Lintas KUA

\begin{tabular}{|c|c|c|c|c|c|c|}
\hline \multirow{2}{*}{$\begin{array}{c}\text { Nama Kantor Urusan Agama } \\
\text { (KUA) }\end{array}$} & \multicolumn{5}{|c|}{ Nikah Pasca Isbat Nikah Lintas KUA } & \multirow[t]{2}{*}{ Jumlah } \\
\hline & 2015 & 2016 & 2017 & 2018 & 2019 & \\
\hline KUA Kecamatan Kota Selatan & 2 & - & - & - & - & 2 \\
\hline KUA Kecamatan Kota Utara & - & - & - & 2 & - & 2 \\
\hline KUA Kecamatan Kota Barat & 4 & 1 & - & - & - & 5 \\
\hline KUA Kecamatan Kota Timur & - & 2 & 1 & - & - & 3 \\
\hline KUA Kecamatan Kota Tengah & - & - & - & - & - & - \\
\hline KUA Kecamatan Dungingi & 1 & - & - & - & - & 1 \\
\hline KUA Kecamatan Dumbo Raya & 4 & 1 & - & - & - & 5 \\
\hline $\begin{array}{l}\text { KUA Kecamatan } \\
\text { Hulonthalangi }\end{array}$ & - & - & - & - & - & - \\
\hline KUA Kecamatan Sipatana & - & - & - & - & - & - \\
\hline & Total & & & & & 18 \\
\hline
\end{tabular}

Sumber: Data Olahan dari KUA Kecamatan di Kota Gorontalo, 2019.

Berdasarkan tabel 1 tersebut diketahui bahwa ada 18 peristiwa nikah pasca isbat nikah yang terjadi di KUA Kecamatan se-Kota Gorontalo sejak tahun 2015 sampai 2019. Terlihat bahwa 2 KUA dalam kurun waktu tersebut belum pernah terjadi peristiwa nikah pasca isbat nikah, yaitu KUA Kecamatan Tengah, KUA Kecamatan Hulonthalangi dan KUA Kecamatan Sipatana.

Tabel 2

Peristiwa Perkawinan dan Pencatatannya di KUA Kota Selatan

\begin{tabular}{|l|l|l|l|}
\hline $\begin{array}{c}\text { Tempat Asal } \\
\text { Suami Istri }\end{array}$ & Tempat Nikah & $\begin{array}{c}\text { No. Penetapan Pengadilan } \\
\text { Agama }\end{array}$ & $\begin{array}{c}\text { No. Register } \\
\text { Nikah }\end{array}$ \\
\hline Kota Selatan & Makassar & 0251/Pdt.P/2014/PA.Gtlo & 050/04/III/2015 \\
\hline Kota Selatan & NAD & 0276/Pdt.P/2015/PA.Gtlo & $161 / 05 / \mathrm{X} / 2015$ \\
\hline
\end{tabular}


Alinda Ahmad Ishak, Muhibbuddin

Tabel 3

Peristiwa Perkawinan dan Pencatatannya di KUA Kota Utara

\begin{tabular}{|c|l|c|c|}
\hline $\begin{array}{c}\text { Tempat Asal } \\
\text { Suami Istri }\end{array}$ & Tempat Nikah & $\begin{array}{c}\text { No. Penetapan Pengadilan } \\
\text { Agama }\end{array}$ & $\begin{array}{c}\text { No. Register } \\
\text { Nikah }\end{array}$ \\
\hline Kota Utara & Lombok & $0251 /$ Pdt.P/2014/PA.Gtlo & $067 / 11 / \mathrm{V} / 2018$ \\
\hline
\end{tabular}

Tabel 4

Peristiwa Perkawinan dan Pencatatannya di KUA Kota Barat

\begin{tabular}{|l|l|l|c|}
\hline $\begin{array}{c}\text { Tempat Asal } \\
\text { Suami Istri }\end{array}$ & Tempat Nikah & $\begin{array}{c}\text { No. Penetapan Pengadilan } \\
\text { Agama }\end{array}$ & No. Register Nikah \\
\hline Kota Barat & Limboto & 0210/Pdt.P/2014/PA.Gtlo & $0040 / 01 / 2 / 2015$ \\
\hline Kota Barat & Balikpapan & 0293/Pdt.P/2015/PA.Gtlo & $0093 / 004 / \mathrm{V} / 2016$ \\
\hline Kota Barat & $\begin{array}{l}\text { Sulawesi } \\
\text { Utara }\end{array}$ & 0208/Pdt.P/2014/PA.Gtlo & $0048 / 007 / \mathrm{II} / 2015$ \\
\hline Kota Barat & $\begin{array}{l}\text { Kota Barat, } \\
\text { diperintahkan } \\
\text { dicatat Kota } \\
\text { Selatan }\end{array}$ & 0225/Pdt.P/2014/PA.Gtlo & $0079 / 014 / \mathrm{V} / 2015$ \\
\hline
\end{tabular}

Tabel 5

Peristiwa Perkawinan dan Pencatatannya di KUA Kota Timur

\begin{tabular}{|c|l|l|c|}
\hline $\begin{array}{c}\text { Tempat Asal } \\
\text { Suami Istri }\end{array}$ & Tempat Nikah & $\begin{array}{c}\text { No. Penetapan Pengadilan } \\
\text { Agama }\end{array}$ & No. Register Nikah \\
\hline Kota Timur & Bitung & 0355/Pdt.P/2015/PA.Gtlo & 002/002/I/2015 \\
\hline Kota Timur & $\begin{array}{l}\text { Kabupaten } \\
\text { Gorontalo }\end{array}$ & 0336/Pdt.P/2015/PA.Gtlo & 003/003/I/2016 \\
\hline
\end{tabular}

Tabel 6

Perkawinan dan Pencatatannya di KUA Dungingi

\begin{tabular}{|c|l|c|c|}
\hline $\begin{array}{c}\text { Tempat Asal } \\
\text { Suami Istri }\end{array}$ & Tempat Nikah & $\begin{array}{c}\text { No. Penetapan Pengadilan } \\
\text { Agama }\end{array}$ & No. Register Nikah \\
\hline Dungingi & Pohuwato & $0288 /$ Pdt.P/2015/PA.Gtlo & $149 / 011 /$ XII/2015 \\
\hline
\end{tabular}


Pencatatan Perkawinan Lintas Kantor Urusan Agama

Di Kota Gorontalo

Tabel 7

Peristiwa Perkawinan dan Pencatatannya di KUA Dumbo Raya

\begin{tabular}{|c|l|l|c|}
\hline $\begin{array}{c}\text { Tempat Asal } \\
\text { Suami Istri }\end{array}$ & Tempat Nikah & $\begin{array}{c}\text { No. Penetapan Pengadilan } \\
\text { Agama }\end{array}$ & No. Register Nikah \\
\hline Dumbo Raya & $\begin{array}{l}\text { Bolaang } \\
\text { Mongondow }\end{array}$ & 0329/Pdt.P/2015/PA.Gtlo & $113 / 09 / \mathrm{XII} / 2015$ \\
\hline Dumbo Raya & Buol & 0349/Pdt.P/2015/PA.Gtlo & $114 / 10 / \mathrm{XII} / 2015$ \\
\hline Dumbo Raya & Kota Utara & 0358/Pdt.P/2015/PA.Gtlo & $115 / 11 / \mathrm{XII} / 2015$ \\
\hline Dumbo Raya & Marisa & 0036/Pdt.P/2016/PA.Gtlo & $037 / 06 / \mathrm{IV} / 2016$ \\
\hline Dumbo Raya & $\begin{array}{l}\text { Sulawesi } \\
\text { Tengah }\end{array}$ & 0349/Pdt.P/2015/PA.Gtlo & 003/003/I/2016 \\
\hline
\end{tabular}

Berdasarkan data tersebut, penulis masih menemukan terjadi pelanggaran administrasi pencatatan perkawinan, yang menyimpang dari asas pencatatan perkawinan sebagaimana diatur dalam Surat Edaran Dirjen dimaksud, di mana praktek pencatatan nikah lintas KUA masih terjadi meskipun dalam skala yang relatif sedikit, karena memang permohonan pencatatan pasca is bät lebih sedikit dibandingkan permohonan pencatatan perkawinan normal. Praktek mal-administrasi yang terjadi pada peristiwa nikah pasca $i \dot{s} b \overline{a t}$.

2. Perkawinan Normal

Adapun pencatatan perkawinan lintas KUA pada perkawinan normal, data yang penulis temukan adalah sebagai berikut:

Tabel 8

Pencatatan di KUA Kecamatan Kota Selatan

\begin{tabular}{|l|c|l|c|}
\hline \multicolumn{2}{|c|}{ Asal Domisili } & \multicolumn{1}{c|}{ Lokasi Menikah } & No. Register Nikah \\
\hline $\begin{array}{l}\text { Suami } \\
\begin{array}{l}\text { Kabisa, } \\
\text { Pohuwato }\end{array}\end{array}$ & Kota Selatan & $\begin{array}{l}\text { Gedung Grand Place, Kota } \\
\text { Tengah }\end{array}$ & $002 / 02 / \mathrm{I} / 2019$ \\
\hline $\begin{array}{l}\text { Kota } \\
\text { Tengah }\end{array}$ & Kota Selatan & $\begin{array}{l}\text { Gedung Graha Azizah, } \\
\text { Kota Barat }\end{array}$ & $003 / 03 / \mathrm{I} / 2019$ \\
\hline $\begin{array}{l}\text { Kota } \\
\text { Selatan }\end{array}$ & Kota Selatan & $\begin{array}{l}\text { Gedung Graha Azizah, } \\
\text { Kota Barat }\end{array}$ & $23 / 04 / \mathrm{III} / 2019$ \\
\hline $\begin{array}{l}\text { Kota } \\
\text { Selatan }\end{array}$ & Kota Selatan & $\begin{array}{l}\text { Gedung Graha Azizah, } \\
\text { Kota Barat }\end{array}$ & $16 / 07 / \mathrm{II} / 2019$ \\
\hline $\begin{array}{l}\text { Kab. } \\
\text { Gorontalo }\end{array}$ & Kota Selatan & $\begin{array}{l}\text { Gedung Grand Place, Kota } \\
\text { Tengah }\end{array}$ & \\
\hline
\end{tabular}


Alinda Ahmad Ishak, Muhibbuddin

Tabel 9

Pencatatan di KUA Kecamatan Kota Utara

\begin{tabular}{|c|c|c|c|}
\hline \multicolumn{2}{|c|}{ Asal Domisili } & \multirow{2}{*}{ Lokasi Menikah } & \multirow{2}{*}{ No. Register Nikah } \\
\hline Suami & Istri & & \\
\hline Dungingi & Kota Utara & $\begin{array}{l}\text { Gedung Graha Azizah, } \\
\text { Kota Barat }\end{array}$ & $009 / 013 / \mathrm{V} / 2016$ \\
\hline Kota Timur & Kota Utara & $\begin{array}{l}\text { Gedung Musdalifah, Kota } \\
\text { Tengah }\end{array}$ & 0095/009/V/2016 \\
\hline Kota Utara & Kota Utara & $\begin{array}{l}\text { Rumah Adat Duluhupa, } \\
\text { Kota Selatan }\end{array}$ & 023/03/III/2019 \\
\hline Kota Barat & Kota Utara & $\begin{array}{l}\text { Gedung Grand Palace, } \\
\text { Kota Tengah }\end{array}$ & 021/01/III/2019 \\
\hline Hulonthalangi & Kota Utara & $\begin{array}{l}\text { Gedung Graha Azizah, } \\
\text { Kota Barat }\end{array}$ & $0125 / / 015 / \mathrm{IX} / 2018$ \\
\hline $\begin{array}{l}\text { Tibawa, Kab. } \\
\text { Gorontalo }\end{array}$ & Kota Utara & $\begin{array}{l}\text { Gedung Graha Azizah, } \\
\text { Kota Barat }\end{array}$ & 0106/011/VIII/2018 \\
\hline $\begin{array}{l}\text { Pasar Rebo, } \\
\text { Jakarta Timur }\end{array}$ & Kota Utara & $\begin{array}{l}\text { Gedung Graha Misfalah, } \\
\text { Kota Tengah }\end{array}$ & 0095/022/VII/2018 \\
\hline $\begin{array}{l}\text { Boliohuto, } \\
\text { Kab. } \\
\text { Gorontalo }\end{array}$ & Kota Utara & $\begin{array}{l}\text { Gedung Graha Azizah, } \\
\text { Kota Barat }\end{array}$ & 0074/001/VII/2018 \\
\hline
\end{tabular}

Tabel 10

Pencatatan di KUA Kecamatan Kota Barat

\begin{tabular}{|l|l|l|c|}
\hline \multicolumn{2}{|c|}{ Asal Domisili } & \multicolumn{1}{c|}{ Lokasi Menikah } & No. Register Nikah \\
\cline { 1 - 2 } $\begin{array}{l}\text { Suami } \\
\text { Kota }\end{array}$ & Kotra Barat & Elgie Hotel, Kota Tengah & $039 / 10 /$ III/2019 \\
\cline { 1 - 2 } Dungingi & Kota Barat & $\begin{array}{l}\text { Rumah Adat Duluhupa, } \\
\text { Kota Selatan }\end{array}$ & $078 / 07 / \mathrm{V} / 2018$ \\
\hline
\end{tabular}

Tabel 11

Pencatatan di KUA Kecamatan Kota Timur

\begin{tabular}{|l|l|l|c|}
\hline \multicolumn{2}{|c|}{ Asal Domisili } & \multicolumn{1}{c|}{ Lokasi Menikah } & No. Register Nikah \\
\cline { 1 - 2 } Sulomi & \multicolumn{1}{|c|}{ Istri } & & $0197 / 006 / \mathrm{XI} / 2018$ \\
\hline Sipatana & Sipatana & $\begin{array}{l}\text { Gorontalo Convention } \\
\text { Center, Kota Selatan } \\
\text { Tengah }\end{array}$ & $0050 / 014 / \mathrm{III} / 2018$ \\
\hline Dumbo Raya & Kota Timur & Graha Azizah, Kota Barat & $004 / 04 / \mathrm{I} / 2019$ \\
\hline
\end{tabular}


Pencatatan Perkawinan Lintas Kantor Urusan Agama

Di Kota Gorontalo

\begin{tabular}{|l|l|l|c|}
\hline Sipatana & Kota Timur & $\begin{array}{l}\text { Grand Sumber Ria, Kota } \\
\text { Utara }\end{array}$ & $02 / 04 / \mathrm{III} / 2019$ \\
\hline Kota Selatan & Kota Timur & Graha Azizah, Kota Barat & $0027 / 06 / \mathrm{III} / 2019$ \\
\hline Tumbihe & Kota Timur & $\begin{array}{l}\text { Gorontalo Convention } \\
\text { Center, Kota Selatan }\end{array}$ & $0216 / 01 / \mathrm{XII} / 2018$ \\
\hline $\begin{array}{l}\text { Desa } \\
\text { Boludawa }\end{array}$ & Dungingi & $\begin{array}{l}\text { Gedung Bele Limbui, } \\
\text { Hulonthalangi }\end{array}$ & $0204 / 013 / \mathrm{XI} / 2018$ \\
\hline Pilolodaa & Kota Timur & $\begin{array}{l}\text { Gorontalo Convention } \\
\text { Center, Kota Selatan }\end{array}$ & $0175 / 013 / \mathrm{X} / 2018$ \\
\hline Kota Timur & Kota Timur & $\begin{array}{l}\text { Rumah Adat Dulohupa, } \\
\text { Kota Selatan }\end{array}$ & $0177 / 015 / \mathrm{X} / 2018$ \\
\hline Dungingi & Kota Timur & Graha Azizah, Kota Barat & $0129 / 007 / \mathrm{VIII} / 2018$ \\
\hline
\end{tabular}

Tabel 12

Pencatatan di KUA Kecamatan Kota Tengah

\begin{tabular}{|l|l|l|c|}
\hline \multicolumn{2}{|c|}{ Asal Domisili } & \multicolumn{1}{c|}{ Lokasi Menikah } & \multirow{2}{*}{ No. Register Nikah } \\
\cline { 1 - 2 } Kota Tengah & Kota Tengah & Graha Azizah, Kota Barat & $00005 / 005 / \mathrm{I} / 2019$ \\
\hline Kota Selatan & Kota Tengah & $\begin{array}{l}\text { Rumah Adat Dulohupa, } \\
\text { Kota Selatan }\end{array}$ & $00008 / 008 / \mathrm{I} / 2019$ \\
\hline $\begin{array}{l}\text { Desa } \\
\text { Wawaone }\end{array}$ & $\begin{array}{l}\text { Desa } \\
\text { Wawaone }\end{array}$ & $\begin{array}{l}\text { Rumah Adat Dulohupa, } \\
\text { Kota Selatan }\end{array}$ & $00009 / 009 / \mathrm{I} / 2019$ \\
\hline $\begin{array}{l}\text { Desa } \\
\text { Wonggarasi }\end{array}$ & Kota Tengah & Graha Azizah, Kota Barat & $00012 / 012 / \mathrm{I} / 2019$ \\
\hline $\begin{array}{l}\text { Kota Tengah } \\
\text { Kota Tengah }\end{array}$ & $\begin{array}{l}\text { Kesa } \\
\text { Buntulio } \\
\text { Selatan }\end{array}$ & $\begin{array}{l}\text { Grand Sumber Ria, Kota } \\
\text { Utara }\end{array}$ & $00016 / 016 / \mathrm{II} / 2019$ \\
\hline Kota Tengah & Kota Tengah & Graha Azizah, Kota Barat & $00032 / 006 / \mathrm{III} / 2019$ \\
\hline
\end{tabular}

Tabel 13

Pencatatan di KUA Kecamatan Dungingi

\begin{tabular}{|l|l|l|c|}
\hline \multicolumn{2}{|c|}{ Asal Domisili } & \multicolumn{1}{c|}{ Lokasi Menikah } & No. Register Nikah \\
\cline { 1 - 2 } $\begin{array}{l}\text { Bulo, Kab. } \\
\text { Bima }\end{array}$ & Dungingi & $\begin{array}{l}\text { Rumah Adat Dulohupa, } \\
\text { Kota Selatan }\end{array}$ & $0203 / 003 / \mathrm{XII} / 2018$ \\
\hline Dungingi & Dungingi & $\begin{array}{l}\text { Rumah Adat Dulohupa, } \\
\text { Kota Selatan }\end{array}$ & $0186 / 004 / \mathrm{XI} / 2018$ \\
\hline
\end{tabular}


Alinda Ahmad Ishak, Muhibbuddin

\begin{tabular}{|l|l|l|c|}
\hline $\begin{array}{l}\text { Cilacap } \\
\text { Tengah }\end{array}$ & Dungingi & $\begin{array}{l}\text { Grand Sumber Ria, Kota } \\
\text { Utara }\end{array}$ & $01 / 95 / 013 / \mathrm{XI} / 2018$ \\
\hline Desa Karamat & Dungingi & $\begin{array}{l}\text { Gedung Grand Palace, } \\
\text { Kota Tengah }\end{array}$ & $029 / 1 / \mathrm{II} / 2019$ \\
\hline Wonosari & Dungingi & $\begin{array}{l}\text { Gedung Graha Azizah, } \\
\text { Kota Barat }\end{array}$ & $33 / 05 / \mathrm{II} / 2019$ \\
\hline Banjer & Dungingi & $\begin{array}{l}\text { Rumah Adat Dulohupa, } \\
\text { Kota Selatan }\end{array}$ & $68 / 26 / \mathrm{III} / 2019$ \\
\hline Hulonthalangi & Dungingi & $\begin{array}{l}\text { Gedung Graha Azizah, } \\
\text { Kota Barat }\end{array}$ & $052 / 10 / \mathrm{III} / 2019$ \\
\hline Dungingi & Desa Lemito & $\begin{array}{l}\text { Gedung Grand Palace, } \\
\text { Kota Tengah }\end{array}$ & $57 / 15 / \mathrm{III} / 2019$ \\
\hline
\end{tabular}

Tabel 14

Pencatatan di KUA Dumbo Raya

\begin{tabular}{|c|c|c|c|}
\hline \multicolumn{2}{|c|}{ Asal Domisili } & \multirow{2}{*}{ Lokasi Menikah } & \multirow{2}{*}{ No. Register Nikah } \\
\hline Suami & Istri & & \\
\hline $\begin{array}{l}\text { Desa Hutuo, } \\
\text { Kab. } \\
\text { Gorontalo }\end{array}$ & $\begin{array}{l}\text { Desa Hutuo, } \\
\text { Kab. } \\
\text { Gorontalo }\end{array}$ & $\begin{array}{l}\text { Gedung Graha Azizah, } \\
\text { Kota Barat }\end{array}$ & 038/13/III/2019 \\
\hline Makassar & $\begin{array}{l}\text { Dumbo } \\
\text { Raya }\end{array}$ & $\begin{array}{l}\text { Gedung Graha Azizah, } \\
\text { Kota Barat }\end{array}$ & 038/13/III/2019 \\
\hline $\begin{array}{l}\text { Desa } \\
\text { Sarimangga }\end{array}$ & $\begin{array}{l}\text { Dumbo } \\
\text { Raya }\end{array}$ & $\begin{array}{l}\text { Hotel Amaris, Kota } \\
\text { Selatan }\end{array}$ & 101/08/IX/2018 \\
\hline
\end{tabular}

Tabel 15

Pencatatan di KUA Kecamatan Hulonthalangi

\begin{tabular}{|c|c|c|c|}
\hline \multicolumn{2}{|c|}{ Asal Domisili } & \multirow{2}{*}{ Lokasi Menikah } & \multirow{2}{*}{ No. Register Nikah } \\
\hline Suami & Istri & & \\
\hline $\begin{array}{l}\text { Bone Raya, } \\
\text { Kab. Bone } \\
\text { Bolango }\end{array}$ & Hulonthalangi & $\begin{array}{l}\text { Gedung Gorontalo } \\
\text { Convention Center, } \\
\text { Kota Selatan }\end{array}$ & 0029/005/III/2019 \\
\hline $\begin{array}{l}\text { Cilincing, } \\
\text { Jakarta }\end{array}$ & Hulonthalangi & $\begin{array}{l}\text { Gedung Gorontalo } \\
\text { Convention Center, } \\
\text { Kota Selatan }\end{array}$ & $0027 / 003 / \mathrm{III} / 2019$ \\
\hline Papua & Hulonthalangi & $\begin{array}{l}\text { Gedung Gorontalo } \\
\text { Convention Center, } \\
\text { Kota Selatan }\end{array}$ & $0002 / 02 / \mathrm{I} / 2019$ \\
\hline
\end{tabular}


Pencatatan Perkawinan Lintas Kantor Urusan Agama

Di Kota Gorontalo

Tabel 16

Pencatatan di KUA Kecamatan Sipatana

\begin{tabular}{|c|c|c|c|}
\hline \multicolumn{2}{|c|}{ Asal Domisili } & \multirow{2}{*}{ Lokasi Menikah } & \multirow{2}{*}{ No. Register Nikah } \\
\hline Suami & Istri & & \\
\hline Minahasa & Sipatana & $\begin{array}{l}\text { Gedung Grand Sumber } \\
\text { Ria, Kota Utara }\end{array}$ & $004 / 04 / 01 / 2019$ \\
\hline Limboto & Sipatana & $\begin{array}{l}\text { Gedung Graha Azizah, } \\
\text { Kota Barat }\end{array}$ & $012 / 01 / \mathrm{II} / 2019$ \\
\hline Kota Utara & Sipatana & $\begin{array}{l}\text { Gedung Grand Sumber } \\
\text { Ria, Kota Utara }\end{array}$ & 013/02/2019 \\
\hline Kota Tengah & Sipatana & $\begin{array}{l}\text { Gedung Gorontalo } \\
\text { Convention Center, Kota } \\
\text { Selatan }\end{array}$ & $122 / 07 / \mathrm{X} / 2018$ \\
\hline Sipatana & Sipatana & $\begin{array}{l}\text { Gedung Gorontalo } \\
\text { Convention Center, Kota } \\
\text { Selatan }\end{array}$ & $138 / 023 / \mathrm{X} / 2018$ \\
\hline Sipatana & Sipatana & $\begin{array}{l}\text { Gedung Gorontalo } \\
\text { Convention Center, Kota } \\
\text { Selatan }\end{array}$ & $145 / 04 / \mathrm{XI} / 2018$ \\
\hline Sipatana & Sipatana & $\begin{array}{l}\text { Masjid Agung } \\
\text { Baiturrahim, Kota Selatan }\end{array}$ & $157 / 016 / \mathrm{XI} / 2018$ \\
\hline Sipatana & Sipatana & $\begin{array}{l}\text { Rumah Adat Dulohupa, } \\
\text { Kota Selatan }\end{array}$ & $164 / 02 / \mathrm{XII} / 2018$ \\
\hline
\end{tabular}

Berdasarkan data-data tersebut, dalam kasus perkawinan normal penyimpangan umumnya terjadi pada perkawinan yang akad nikah serta resepsinya dilangsungkan di gedung resepsi perkawinan yang terletak di luar kecamatan domisili para calon pengantin, sementara berkas administrasi pencatatannya terlanjur didaftarkan di KUA Kecamatan domisilinya. Sementara untuk kasus pasca $i \ddot{s} b \bar{a} t$, penyimpangan terjadi karena pelakunya pindah domisili. Seharusnya dalam kasus seperti ini, KUA tempat domisili pengantin memberikan rekomendasi kepada KUA tempat berlangsunya perkawinan untuk melakukan pencatatan perkawinan, bukan KUA yang bersangkutan pergi melaksanakan perkawinan di gedung yang letaknya jelasjelas berada di luar wilayah kecamatannya.

Sebagai gambaran pencatatan nikah yang terjadi di 9 (Sembilan) KUA Kecamatan se-wilayah Kota Gorontalo sejak tahun 2015 sampai Februari 2019 dapat dilihat dalam tabel berikut: 
Alinda Ahmad Ishak, Muhibbuddin

Tabel 17

Pencatatan Nikah di 9 KUA Kecamatan di Kota Gorontalo

Tahun 2015 - Februari 2019

\begin{tabular}{|c|c|c|c|c|c|c|c|c|c|c|c|c|c|c|c|c|}
\hline \multirow{2}{*}{$\mathbf{N}_{0}$} & \multirow{2}{*}{ Nan KTA } & \multicolumn{3}{|c|}{2015} & \multicolumn{3}{|c|}{2016} & \multicolumn{3}{|c|}{2 2i17 } & \multicolumn{3}{|c|}{2018} & \multicolumn{3}{|c|}{2019} \\
\hline & & PN & PPI & LITA & PN & PPI & L.KTA & $\mathrm{PN}$ & $\mathrm{PPI}$ & LKTTA & $\mathrm{N}$ & $\mathrm{PH}$ & LITA & PS & $\mathrm{PPI}$ & LITA \\
\hline 1 & ITt Kec. Selatn & 198 & 21 & 2 & 181 & 3 & - & 171 & 3 & - & 194 & 1 & - & 9 & - & - \\
\hline 2 & KTtA Ker Ttan & 199 & 6 & - & 218 & 15 & - & 181 & 5 & - & 182 & 3 & 1 & 15 & $\cdot$ & - \\
\hline 3 & ETI Kee. Bant & 227 & 7 & 4 & 196 & 2 & 1 & 209 & 2 & - & 223 & - & - & 16 & - & - \\
\hline 4 & ITt Kec. Tinur & 226 & 9 & & 217 & 3 & 1 & 214 & 3 & 1 & 226 & 1 & . & 10 & $\cdot$ & - \\
\hline 5 & ITt Ker. Tengih & 195 & $\cdot$ & - & 192 & 4 & - & 184 & - & - & 219 & 1 & - & 15 & $\cdot$ & - \\
\hline 6 & KTA Ker. Dungingi & - & 2 & 1 & 140 & - & - & 182 & 1 & - & 200 & - & - & 28 & - & - \\
\hline 7 & ITI Kee Dumbo Rụ & 120 & 10 & 4 & 167 & 1 & 1 & 152 & - & - & 151 & $\cdot$ & - & 14 & - & - \\
\hline 8 & KTA Kec. Huloathalngi & 91 & $\cdot$ & - & 194 & 4 & - & 129 & 1 & - & 148 & $\cdot$ & - & 12 & - & - \\
\hline 9 & ITt Kec. Sipan & - & - & - & - & - & - & 139 & - & - & 170 & - & - & 11 & - & - \\
\hline
\end{tabular}

Keterangan: $\mathrm{PN}=$ Perkawianan Normal, $\mathrm{PPI}=$ Perkawinan Pasca Isbat, L.KUA= Lintas KUA

Berdasarkan pada tabel 17 dapat dilihat dari 9 KUA Kecamatan di wilayah Kota Gorontalo, dalam rentan waktu 2015 sampai dengan 2019, setidak-tidaknya ada 7 (tujuh) KUA yang melaksanakan pencatatan lintas KUA pasca iśbät yaitu KUA Kecamatan Kota Selatan sebanyak 2 (dua) Peristiwa Nikah, KUA Kecamatan Kota Utara 1 (satu) Peristiwa Nikah, KUA Kecamatan Kota Barat sebanyak 4 (empat) Peristiwa Nikah, KUA Kecamatan Kota Timur sebanyak 2 (dua) Peristiwa Nikah, KUA Kecamatan Dungingi sebanyak 1 (satu) Peristiwa Nikah dan KUA Kecamatan Dumbo Raya sebanyak 5 (lima) peristiwa nikah. Itu berarti bahwa Surat Edaran Dirjen Bimas Islam Nomor: D II.2/1/HM.01/942/2009 tentang asas pencatatan perkawinan belum berjalan maksimal di wilayah Kota Gorontalo.

Hasil wawancara yang penulis lakukan terhadap Penghulu/PPN di Kota Gorontalo, dari 9 (Sembilan) KUA Kecamatan, 7 diantaranya belum pernah membaca isi Surat Edaran dimaksud, kecuali setelah penulis memperlihatkannya. Berdasarkan itu dapat dipastikan bahwa penyebab utama tidak terlaksananya maksud dari perintah Surat Edaran tersebut adalah karena tidak tersosialisasikannya Surat Edaran tersebut ke tangan para pemangku kebijakan dalam hal ini Penghulu/PPN di wilayah Kota Gorontalo. 
Peristiwa seperti ini patut dipertanyakan dan dikritisi, mengingat maksud dari dikeluarkannya surat edaran tersebut adalah karena adanya praktek mal-administrasi di kalangan KUA Kecamatan di seluruh wilayah Republik Indonesia sehubungan dengan asas pencatatan ini, sebagaimana tergambar dalam konsideran angka (4) Surat Edaran tersebut:

Sehubungan dengan masih adanya pencatatan perkawinan yang dilakukan oleh PPN di luar wilayah hukumnya (termasuk pencatatan perkawinan di luar negeri, sebagai contoh di Mekkah Saudi Arabia dengan PPN dari Indonesia), kami minta agar saudara memerintahkan kepada apparat di wilayah saudara untuk mematuhi dan melaksanakan ketentuan di atas. ${ }^{26}$

Semua Penghulu/PPN yang berada di 9 KUA Kecamatan di Kota Gorontalo "berlindung" di balik Penetapan Pengadilan Agama Gorontalo yang dalam amar penetapannya memerintahkan para Pemohon (kedua mempelai) untuk mencatatkan perkawinannya pada KUA tertentu yang berbeda dengan domisili kedua mempelai (bukan pada KUA tempat terjadinya perkawinan). Padahal sebuah Penetapan yang sifatnya volunter tidak mengikat pihak ketiga di luar pihak-pihak internal dalam hal ini Pemohon I (calon suami) dan Pemohon II (calon istri). ${ }^{27}$ Dengan kata lain Penghulu/PPN seharusnya dapat menolak permohonan pencatatan tersebut, selama isi dari penetapan tersebut bertentangan dengan asas hukum pencatatan perkawinan, yaitu asas peristiwa nikah.

Terkait apabila di amar Putusan Penetapan Pengadilan tidak mencantumkan nama KUA untuk registrasi pernikahan, maka semua Penghulu/PPN yang berada di 9 (sembilan) KUA Kecamatan di Kota Gorontalo tetap akan menerima dan mencatatnya, meskipun realitasnya perkawinan tersebut dahulu dilaksanakan di luar wilayah hukumnya, dengan pertimbangannya faktor kasihan dan tidak mau merepotkan kedua mempelai. Hal ini terkesan sangat dilematis di satu sisi negara menginginkan tertib admistrasi pencatatan perkawinan agar betul-betul dijalankan dan ditegakkan tanpa pandang bulu, tetapi di sisi lain aturan

\footnotetext{
${ }^{26}$ Kementerian Agama RI, Himpunan Peraturan Perundang-Undangan Tentang Perkawinan (Jakarta: Direktur Urusan Agama Islam dan Pembinaan Syari'ah, Direktorat Jenderal Bimbingan Masyarakat Islam, 2015), h. 703.

${ }^{27}$ M. Yahya Harahap, Hukum Acara Perdata, Tentang Gugatatan, Persidangan, Penyitaan, Pembuktian dan Putusan Pengadilan, (Cet. Ke-9, Jakarta: Sinar Grafika, 2009), h. 40-41.
} 
tersebut dipandang sebelah mata oleh Penghulu/PPN sendiri hanya karena persoalan subyektif. Oknum aparat Penghulu/PPN yang bersikap seperti ini, patut dikritisi dan dievaluasi kembali keberadaannya mengingat, merekalah yang menjadi kawal depan Kementerian Agama dalam hal tertib administrasi perkawinan.

Ini berarti bahwa semua Penghulu/PPN yang berada di 9 KUA Kecamatan di Kota Gorontalo masih menerima dan melakukan pencatatan perkawinan terhadap perkawinan yang peristiwanya dilaksanakan di luar wilayah hukumnya. Sementara peraturan perundangan menghendaki bahwa pencatatan nikah hanya dapat dilakukan dalam wilayah hukum masingmasing KUA Kecamatan, maka yang menjadi pertanyaan mendasar adalah bagaimana status hukum dari pencatatan perkawinan tersebut, jika dianalisis dengan menggunakan teori kewenangan. ${ }^{28}$ Menurut Indroharto, ada tiga macam kewenangan yang bersumber dan peraturan perundang-undangan. Kewenangan tersebut, meliputi: (a) atribusi; ${ }^{29}$ (b) delegasi ${ }^{30}$ dan (c) mandat. ${ }^{31}$ Sementara itu Philipus M. Hadjon membagi cara memperoleh

\footnotetext{
${ }^{28}$ Ridwan HR. Hukum Administrasi Negara (Jakarta: RajaGrafindo Persada, 2008), 104.

${ }^{29}$ Atribusi ialah pemberian kewenangan oleh pembuat undang-undang sendiri kepada suatu organ pemerintahan, baik yang sudah ada maupun yang baru sama sekali. Dengan kata lain, atribusi berarti timbulnya kewenangan baru yang sebelumnya kewenangan itu, tidak dimiliki oleh organ pemerintah yang bersangkutan.

${ }^{30}$ Delegasi adalah penyerahan wewenang yang dipunyai oleh organ pemerintahan kepada organ yang lain. Dengan kata penyerahan, ini berarti adanya perpindahan tanggung jawab dan yang memberi delegasi (delegans) kepada yang menerima delegasi (delegetaris). Lihat Philipus M. Hadjon, "Tentang Wewenang Pemerintahan (Bestuurbevoegdheid), Pro Justitia, Tahun XVI Nomor I Januari 1998, 94. Dalam delegasi mengandung suatu penyerahan, yaitu apa yang semula kewenangan si A, untuk selanjutnya menjadi kewenangan si B. Kewenangan yang telah diberikan oleh pemberi delegasi selanjutnya menjadi tanggung jawab penerima wewenang. F.A,M. Stroink dan J.G. Steenbeek, seperti dikutip oleh Ridwan HR, mengemukakan ada dua cara organ pemerintah memperoleh kewenangan, yaitu: atribusi; dan delegasi. Atribusi berkenaan dengan penyerahan wewenang baru, sedangkan delegasi menyangkut pelimpahan wewenang yang telah ada (oleh organ yang telah memperoleh wewenang secara atributif kepada organ lain; jadi secara logis selalu didahului oleh atribusi). Lihat Ridwan HR. Hukum Administrasi Negara, 105.

${ }^{31}$ Mandat diartikan suatu pelimpahan wewenang kepada bawahan. Pelimpahari itu bermaksud memberi wewenang kepada bawahan untuk membuat keputusan a/n pejabat Tata Usaha Negara yang memberi mandat. Tanggungjawab tidak berpindah ke mandataris, melainkan tanggungjawab tetap berada di tangan pemberi mandat, hal ini dapat dilihat dan kata a.n (atas nama). Dengan demikian, semua akibat hukum yang ditimbulkan oleh adanya keputusan yang dikeluarkan oleh mandataris adalah tanggung jawab si pemberi mandat.
} 


\section{Pencatatan Perkawinan Lintas Kantor Urusan Agama \\ Di Kota Gorontalo}

wewenang atas dua cara, yaitu: atribusi dan delegasi, terkadang-kadang juga mandat. $^{32}$

Terkait pencatatan perkawinan oleh Penghulu/PPN merupakan kewenangan atributif, karena kewenanganya itu diperoleh langsung dari undang-undang. Dalam hal ini, kewenangan mencatat peristiwa nikah oleh Penghulu/PPN diatribusikan melalui Pasal 5 ayat (2), ${ }^{33}$ Pasal 6 ayat (1) dan $(2)^{34}$ Undang-Undang Nomor 1 Tahun 1974 tentang Perkawinan Jo. Peraturan Pemerintah No. 9 Tahun 1975, tentang Pelaksanaan UU. No. 1 Tahun 1974 tentang Perkawinan. ${ }^{35}$

Berdasarkan ketentuan tersebut, kewenangan mencatat sebuah peristiwa nikah hanya boleh dilakukan oleh organ pemerintah dalam hal ini Penghulu/PPN sesuai dengan yang diatribusikan oleh peraturan perundangan, yaitu di wilayah hukumnya masing-masing, itu artinya apabila ada seorang Penghulu/PPN yang nekat mencatat peristiwa nikah di luar wilayah hukumnya, maka pencatatannya dianggap cacat hukum, sehingga

Sebagai suatu konsep hukum publik, wewenang terdiri atas sekurang-kurangnya tiga komponen, yaitu: pengaruh, dasar hukum; dan konformitas hukum. Lihat Philipus M. Hadjon, "Tentang Wewenang Pemerintahan (Bestuurbevoegdheid), Pro Justitia, Tahun XVI Nomor I Januari 1998, 90.

${ }^{32}$ Philipus M. Hadjon, "Tentang Wewenang Pemerintahan," 94.

${ }^{33}$ Bunyi teksnya adalah: (2) Pencatatan perkawinan tersebut pada ayat (1) dilakukan oleh Pegawai Pencatat Nikah sebagaimana diatur dalam UU No. 22 Tahun 1966 jo UU No. 32 Tahun 1954.

${ }^{34}$ Bunyi teksnya adalah: (1) Untuk memenuhi ketentuan pasal 5, setiap perkawinan harus dilangsungkan di hadapan dan di bawah pengawasan Pegawai Pencatat Nikah; 2). Perkawinan yang dilakukan di luar pengawasan Pegawai Pencatat Nikah tidak mempunyai kekuatan hukum

${ }^{35}$ Secara lebih rinci, pasal 2 menjelasakan tentang pencatatan perkawinan: 1).Pencatatan perkawinan dari mereka yang melangsungkan perkawinannya menurut agama Islam, dilakukan oleh pegawai pencatat sebagaimana dimaksudkan dalam UU No. 32 Tahun 1954 tentang pencatatan nikah, Talak, dan Rujuk; 2). Pencatatan perkawinan dari mereka yang melangsungkan perkawinannya menurut agamanya dan kepercayaannya itu selain agama Islam, dilakukan oleh Pegawai Pencatat Perkawinan pada kantor catatan sipil sebagaimana dimaksud dalam berbagai perundang-undangan mengenai pencatatan perkawinan; 3). Dengan tidak mengurangi ketentuan-ketentuan yang khusus berlaku bagi tata cara pencatatan perkawinan berdasarkan berbagai peraturan yang berlaku , tata cara pencatatan perkawinan dilakukan sebagaimana ditentukan dalam pasal 9 PP ini . Pasal 3 PP No. 9 Tahun 1975 menyatakan: "Setiap orang yang akan melangsungkan perkawinan memberitahukan kehendaknnya itu kepada Pegawai Pencatat di tempat perkawinan akan dilangsungkan." 
secara adminitratif buku Kutipan Akta Nikah yang dikeluarkannya dianggap tidak mempunyai legalitas. Satu-satunya cara agar pencatatannya legal menurut teori kewenangan, Penghulu/PPN yang bersangkutan harus mendelegasikan kewenangannya kepada Penghulu/PPN yang mewilayahi tempat berlansungnya perkawinan. Inilah yang dimaksud dari dikeluarkannya Surat Edaran Dirjen Bimas Islam Nomor: DII.2/1/HM.01/942/2009 tentang Asas Pencatatan Perkawinan.

\section{E. Penutup}

Bahwa 7 (tujuh) dari 9 (sembilan) KUA Kecamatan di Kota Gorontalo Penghulu/PPN-nya belum mengetahui/membaca Surat Edaran Dirjen Bimas Islam Nomor: D II.2/1/HM.01/942/2009 tentang asas pencatatan perkawinan, sementara 2 (dua) dari 9 (sembilan) KUA Kecamatan di Kota Gorontalo yang pernah membacanya terpecah menjadi dua kelompok, yang pertama, berasumsi bahwa maksud dari surat edaran tersebut hanya berlaku untuk perkawinan normal, tidak berlaku untuk perkawinan pasca iśbàt. Sementara kelompok kedua meskipun berpendapat sebaliknya tetapi kalau dihadapkan kepada kasus nyata (di lapangan) pencatatan lintas KUA pasca iśbät, tetap akan menerima dan mencatatnya walaupun tidak sesuai dengan isi dari surat edaran, dalam kasus pasca išba tergantung pada isi penetapan $i \dot{s} b \bar{a} t$-nya;

Bahwa realitas pencatatan perkawinan lintas KUA di Kota Gorontalo tidak berjalan sesuai dengan aturan yang terdapat dalam Surat Edaran Dirjen Bimas Islam Nomor: D II.2/1/HM.01/942/2009 tentang asas pencatatan perkawinan, bahkan terkesan diabaikan oleh semua Penghulu/PPN di 9 (sembilan) KUA Kecamatan di Kota Gorontalo;

\section{Daftar Pustaka}

Anshary M.K. Hukum Perkawinan di Indonesia. Cet. II; Yogyakarta: Pustaka Pelajar, 2015.

Harahap, M. Yahya. Hukum Acara Perdata, Tentang Gugatatan, Persidangan, Penyitaan, Pembuktian dan Putusan Pengadilan. Cet. IX; Jakarta: Sinar Grafika, 2009. 


\section{Pencatatan Perkawinan Lintas Kantor Urusan Agama}

Di Kota Gorontalo

Mahkamah Agung RI. Himpunan Peraturan Perundang-Undangan di Lingkungan Peradilan Agama. Jakarta: Direktorat Jenderal Badan Peradilan Agama, 2016.

Nasution, Khairuddin. Hukum Perdata (Keluarga) Islam Indonesia dan Perbandingan Hukum Perkawinan di Dunia Muslim. Yogyakarta: Academia \& Tazzafa, 2009.

Penetapan Pengadilan Agama Kediri Nomor: 0054/Pdt.P/2016/PA.Kdr.

Penetapan Pengadilan Agama Gorontalo Nomor 0251/Pdt.P/2014/PA.Gtlo

Penetapan Pengadilan Agama Gorontalo Nomor 0276/Pdt.P/2015/PA.Gtlo

Philipus M. Hadjon. "Tentang Wewenang Pemerintahan (Bestuurbevoegdheid), Pro Justitia, Tahun XVI Nomor I Januari 1998.

Republik Indonesia. Peraturan Menteri Agama Nomor 11 Tahun 2017 tentang Pencatan Perkawinan

- Peraturan Pemerintah Nomor 9 Tahun 1975 tentang Pelaksanaan Undang-Undang Nomor 1 Tahun 1974 tentang Perkawinan . Undang-Undang Nomor 1 Tahun 1974 tentang Perkawinan - Undang-Undang Nomor 22 Tahun 1946 tentang Pencatatan Perkawinan, Talak dan Rujuk

- Undang-Undang Nomor 32 Tahun 1954 tentang Penetapan Berlakunya Undang-Undang Republik Indonesia Tanggal 21 Nopember 1946 Nomor 22 Tahun 1946 tentang Pencatatan Perkawinan, Talak dan Rujuk di Seluruh Daerah Luar Jawa dan Madura

Ridwan HR. Hukum Administrasi Negara. Jakarta: RajaGrafindo Persada, 2008.

http://int anghina.wordpress.com/2008/05/27/analisis-yuridis-stat us-hukumistri-yang-menikah-di-bawah-tangan-berdasarkan-ketentuan-yangberlaku-tentang-perkawinan

https://putusan.mahkamahagung.go.id

www.pa-gorontalo.go.id 